\title{
流体を伝えるつぶれやすい管の安定性解析* (剥離点の移動に伴う擾乱と下流流路の長さの影響について)
}

青松達哉*1, 松 崎雄 嗣*2, 池田忠繁*2

\section{Stability Analysis of a Collapsible Tube Conveying Fluid \\ (On Effects of Perturbations Induced by Movement of Separation Point and Length of Downstream Channel)}

\author{
Tatsuya AOMATSU*3, Yuji MATSUZAKI and Tadashige IKEDA \\ ${ }^{* 3}$ Department of Aerospace Engineering, Nagoya University, \\ Furou-cho, Chikusa-ku, Nagoya-shi, Aichi, 464-8063 Japan
}

\begin{abstract}
Stability of the steady state of a collapsible tube conveying fluid is investigated, using a twodimensional flexible channel model. The model consists of a pair of elastic membranes supported by distributed nonlinear springs equivalent to the hoop tension of the tube. Perturbation equations are numerically solved using a shooting method. In the present study examined are the effects of (1) perturbations of spatial distributions of separation coefficient and viscous resistance induced by the movement of separation point and (2) a length of downstream rigid channel connected to the collapsible segment on the stability. The results show that, depending on the length of downstream channel and the flow rate, the steady states become unstable to different modes of osicillation, while the perturbations induced by the movement of separation point does not affect the stability very much.
\end{abstract}

Key Words: Flow Induced Vibration, Internal Flow, Bio-Fluid Mechanics, Biomechanics, Collapsible Tube, Stability Analysis

\section{1. 緒言}

柔らかく，つぶれやすい管（コラプシブルチュー ブ）の中を流体が流れると，流れと管の変形とが相互 に作用し，条件次第で自励振動が起こる場合がある(1).

コラプシブルチューブの自励振動を解明することは, 声の音源である声帯の振動(や，人工心肺装置の脱血 回路に接続された大静脈の振動 ${ }^{(3)}$ 等, 生理的現象の理 解や臨床医学上の問題の解決につながると考えられ， 従来から数多くのモデル実験 ${ }^{(4) \sim(7)}$ や数値解析 ${ }^{(8) \sim(13)}$ が 行われている。

数值解析において, Matsuzaki ら ${ }^{(9)(10)}$ は, チューブ の代わりに，チューブ則 ${ }^{(14)}$ （チューブに作用する内外 圧力差とチューブの断面積との関係）に従う上下二枚 の弾性膜に挟まれた二次元流路の静的・動的特性を調 べ，弾性流路の下流に接続された剛な流路の長さによ り振動の様子が大きく変化することを示している ${ }^{(9)}$. また，実験においても，下流の流路抵抗の変化に対し

* 原稿受付 2000 年 5 月 8 日

*1 正員, 名古屋大学 (五 464-8603 名古屋市千種区不老町).

$* 2$ 正員, 名古屋大学大学院工学研究科.

E-mail : aomatsu@smart.nuae.nagoya-u.ac.jp
て，自励振動するシリコンゴムチューブの上流と下流 での静圧の時間履歴は，正弦波に似た単純な波形から いくつかの振動数の波が含まれる複雑な波形まで, 多 様に変化することが観察されている ${ }^{(7)}$.

このような自励振動のパターンの多様性は，コラプ シブルチューブとその中を流れる流体，そして下流の 流路抵抗を含む周辺回路からなる系の非線形性に起因 するため, その解析は容易でない.しかしながら, 系 は, 流量などのパラメーターの変化に対して静的な平 衡状態が不安定化する過程を経て, 自励振動に至るこ とから，微小擾乱に対する安定性を調べることにより， 振動パターンの変化の様子をある程度知ることができ， また，この問題は線形化により定式化されるため, 解 析は比較的容易になる.

そこで，本報では，Matsuzaki ら ${ }^{(9)(10)}$ により提案さ れた二次元弾性流路モデルを用いて，流量と下流流路 の長さからなるパラメーター空間における系の不安定 領域を調べる。

コラプシブルチューブの定常解の安定性に関しては Jensen の研究 ${ }^{(13)}$ があるが，そこでは剥離点の移動に 伴う剥離係数や粘性抵抗の分布の変化（以降, 剥離点 
の移動に伴う擾乱と呼ぶ）は考慮されていない．しか し, 物理的観点から, 剥離係数や粘性抵抗の分布は流 路内の圧力分布に直接影響するため, 剥離点の移動に 伴うそれらの分布の変化を考慮することは重要である と考えられる.

この剥離点の移動に伴う擾乱が系の安定性に与える 影響に対して明確な結論を出すことも重要であるので, 本報では, まず, 剥離点の移動に伴う擾乱を考慮して 微小擾乱に対する定常解の安定性を調べ, 次に, 先に 述べた下流の剛な流路の長さの影響について調べる.

\section{2. 数 学 モ $テ ゙$ ル}

$2 \cdot 1$ 二次元弾性流路モデル Matsuzaki ら により提案された二次元弾性流路モデルの概要を説明 する. モデルは図 1 に示すようにコラプシブルチュー ブ流れの実験装置と対忘している. チューブは, 分布 バネに外側から支持された上下二枚の弾性膜からなる 二次元流路に置き換えられている，流体は図において 向かって左側から右側に流れる. 最上流にある一定の 水頭圧 $P_{r}$ の貯水槽から流出した流体は, 長さ $L_{1}$, 幅 $2 B_{0}$ の剛な平行流路を通り弾性流路に入る. 長さ $L$,

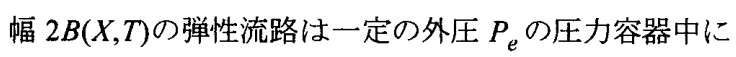
設置され, 流路はチューブ則に従う復元力の非線形バ ネにより支持されている，弾性流路を通過した流体は その下流にある長さ $L_{2}$, 幅 $2 B_{0}$ の剛な平行流路を経て, 大気中に放出される.ただし, 原点の位置を弾性流路 の上流端の中央にとり, 流れの方向に $X$ 軸, それに垂 直に $Z$ 軸をとる. また, 上下の弾性膜は $Z$ 軸方向にの み運動し， $X$ 軸に関し対称に変形すると仮定している. $2 \cdot 2$ 弾性膜の運動方程式 膜の微小要素に作用 する力の $Z$ 軸方向の釣合を考えると, 弾性膜の運動方 程式は以下のようになる.

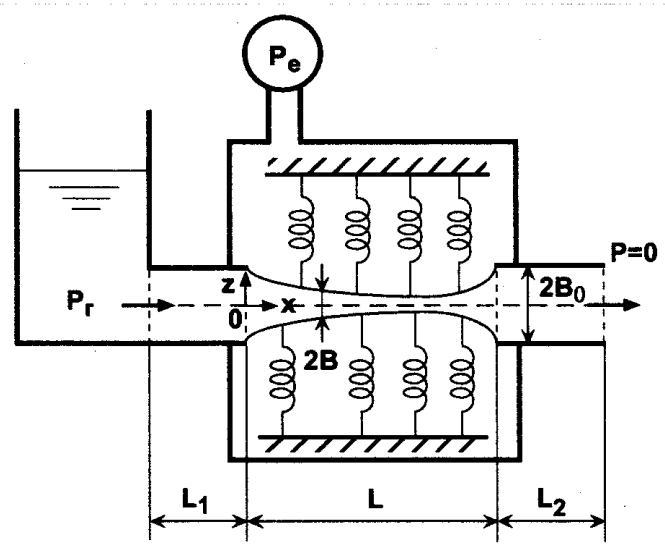

Fig. 1 Two-dimensional flexible channel model

$$
\rho_{m} H B,_{T T}+C_{m} B_{, T}+R_{k}(B)-N K=P-P_{e} \cdots
$$
ただし， $\rho_{m}, H, C_{m}, R_{k}(B), N, K, P$ はそれぞれ膜 の密度, 厚さ, 減衰係数, 非線形バネの復元力, 膜に 働く軸方向の張力, 膜の曲率, 膜に作用する流体の静 圧である。また，添え字「’T」，「'TT」はそれぞれ時間 $T$ による一階, 二階の偏微分を表す. 以降, 添え字「’ は同様な偏微分を表す。

非線形バネの復元力は, Elad ら ${ }^{(15)}$ が考案したチュ ーブ則を参考にし,

$$
R_{k}(B)=K_{P}\left\{\left(\frac{B}{B_{0}}\right)^{20}-\left(\frac{B}{B_{0}}\right)^{-1.5}\right\}
$$

ただし，

$$
K_{P}=\frac{E}{12\left(1-v_{m}^{2}\right)}\left(\frac{H}{B_{0}}\right)^{3}
$$

とする. $E, v_{m}$ は, それぞれヤング率, ポアソン比で ある. 図 2 に上式に基づくチューブ則と，対応するチ ューブ断面の概略形状を示す.

弾性膜は自然長から伸展した状態で上流, 下流の剛 な流路に接続されているので初期張力が存在し, また, 膜のたわみにより付加的な張力が誘起されるので, 膜 に働く張力 $N$ は, 初期歪, たわみによる歪みをそれぞ れ $\varepsilon_{0}, \varepsilon_{x}$ として，以下のように表すことができる.

$$
N=K_{S}\left(\varepsilon_{0}+\varepsilon_{x}\right)
$$

ただし,

$$
K_{S}=\frac{E H}{1-v_{m}^{2}}, \varepsilon_{x}=\frac{1}{2 L} \int_{0}^{L}\left(B,{ }_{X}\right)^{2} d X
$$

さらに曲率 $K$ は以下の式で与える.

$$
K=B,{ }_{X X}\left\{1+(B, X)^{2}\right\}^{-1.5}
$$

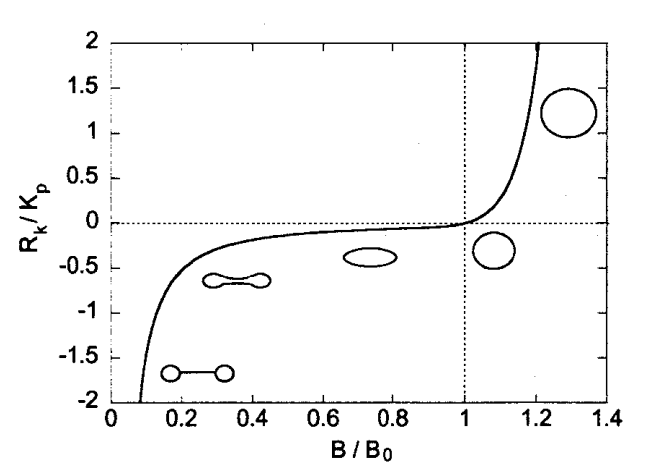

Fig.2 Relationships between the restoring force of the nonlinear springs and the channel width 
$2 \cdot 3$ 流体の方程式 Matsuzaki ら ${ }^{(9)(10)}$ は, 流れ の剥離を考慮した Cancelli-Pedley ${ }^{(8)}$ の一次元流モデル に基づき, 流体の連続方程式と運動方程式を以下の式 で表した。

$$
\begin{gathered}
B,_{T}+(B U)_{,_{X}}=0 \cdots \cdots \cdots \cdots \cdots \cdots \cdots \cdots \cdots \cdots(1.2 \mathrm{a}) \\
U,_{T}+\bar{\chi} U U,_{X}=-\frac{1}{\rho} P,_{X}-F(U, B) ; F(U, B)=\frac{3 v U}{B^{2}} G
\end{gathered}
$$

ただし， $U, \bar{\chi}, \rho, v は$ 断面内平均流速, 剥離係数, 流体の密度と動粘性係数である. 粘性抵抗 $F$ は二次元 Poiseuille 流れの仮定により与えた。

剥離係数と粘性抵抗は剥離点近傍で連続的に変化す るように $\bar{\chi}$ とを以下の関数で与える.

$$
\begin{aligned}
& \bar{\chi}\left(X, X_{S}\right)=0.6-0.4 \tanh \left\{A\left(X-X_{S}\right)\right\} \cdots(1.3 \mathrm{a}) \\
& G\left(X, X_{S}\right)=0.5\left[1-\tanh \left\{A\left(X-X_{S}\right)\right\}\right] \cdots(1.3 \mathrm{~b})
\end{aligned}
$$

$X_{S}$ は剥離点の位置, $A$ は剥離点での関数の勾配に関わ る定数である. $\bar{\chi}\left(X, X_{S}\right)$ と $G\left(X, X_{S}\right)$ の概形を図 3 に 示す. 寸なわち, 剥離係数 $\bar{\chi}$ は, 剥離点より十分に上 流では 1.0, 下流では 0.2 の值とし，剥離領域では粘性 抵抗の值を 0 とする. また, 流路が膨張しているとき 流れは剥離しないものとする。

また，流れは流路幅が最小となる位置で剥離し，弾 性流路の下流端で再付着すると仮定する。つまり, 剥 離条件を次式で与える。

$$
B,{ }_{X}\left(X_{S}, T\right)=0 \cdots \cdots \cdots \cdots \cdots \cdots \cdots \cdots \cdots \cdots \cdots
$$

$2 \cdot 4$ 境界条件弾性膜はその両端で剛な平行流 路に接続されているので,

$$
B(0, T)=B(L, T)=B_{0}
$$

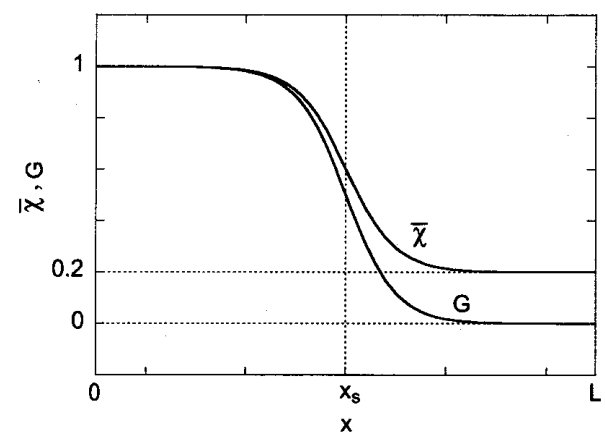

Fig. 3 Continuous changes in separation coefficient $\bar{\chi}$ and viscous resistance parameter $G$ across the separation point at $X=X_{S}$
となる，また，上流端，下流端の静圧は，貯水槽で総 圧が $P_{r}$, 大気開放部で静圧が 0 であることを考慮して, 流体の方程式(1.2)をそれぞれの剛な平行流路の長さに 渡り積分することにより得られる。

$$
\begin{array}{r}
P(0, T)=P_{r}-\frac{1}{2} \rho\{U(0, T)\}^{2}-\rho L_{1} U,_{T}(0, T) \\
-\rho L_{1} F\left(U(0, T), B_{0}\right) \cdots \cdots \cdots(1 .
\end{array}
$$

$$
P(L, T)=\rho L_{2} U,_{T}(L, T)+\rho L_{2} F\left(U(L, T), B_{0}\right)
$$

$2 \cdot 5$ 無次元化 無次元化の基準量として, 長さ, 流速，圧力，時間に関してそれぞれ $B_{0}, C_{0}, \rho C_{0}{ }^{2}$, $B_{0} / C_{0}$ を用いる. $C_{0}=\left\{\left(21.5 K_{p}\right) / \rho\right\}^{1 / 2}$ は自然状態にあ るチューブ内の静止流体中を伝わる圧力波の伝播速度 である. 無次元化した変数等をアルファベットの小文 字で表すと, 弾性膜の運動方程式 (1.1), 流体の方程 式 (1.2), 剥離条件 (1.4), 境界条件 (1.5)は以下のよ うになる。

$$
\begin{aligned}
& m b,_{t t}+c b b_{t}+r_{k}(b)-n \kappa=p-p_{e} \cdots \cdots \cdots \cdots(2.1) \\
& b_{, t}+(b u)_{,_{x}}=0 \cdots \cdots \cdots \cdots \cdots \cdots \cdots \cdots \cdots \cdots \cdots(2.2 \mathrm{a}) \\
& u_{t}+\chi u u_{x}=-p,_{x}-f \frac{u}{b^{2}} \\
& b,_{x}\left(x_{s}, t\right)=0 \\
& b(0, t)=b(l, t)=1 \\
& p(0, t)=p_{r}-\frac{1}{2}\{u(0, t)\}^{2}-l_{1} u,_{t}(0, t)-l_{1} f_{i} u(0, t) \\
& p(l, t)=l_{2} u, t(l, t)+l_{2} f_{i} u(l, t) \\
& x=X / B_{0}, t=T /\left(B_{0} / C_{0}\right), b=B / B_{0}, p=P /\left(\rho C_{0}{ }^{2}\right), \\
& u=U / C_{0}, n=N /\left(\rho C_{0}{ }^{2} B_{0}\right), l=L / B_{0}, e t c ., \\
& r_{k}(b)=k_{p}\left(b^{20}-b^{-1.5}\right), n=k_{s}\left\{\varepsilon_{0}+\frac{1}{2 l} \int_{0}^{l}(b, x)^{2} d x\right\}, \\
& \kappa=b,,_{x x}\left\{1+(b,)^{2}\right)^{-1.5}, \\
& \chi\left(x, x_{s}\right)=0.6-0.4 \tanh \left\{a\left(x-x_{s}\right)\right\}, \\
& f=f_{i} g, g\left(x, x_{s}\right)=0.5\left[1-\tanh \left\{a\left(x-x_{s}\right)\right\}\right] \text {, } \\
& m=\frac{\rho_{m} H}{\rho B_{0}}, c=\frac{C_{m}}{\rho C_{0}}, k_{p}=\frac{K_{P}}{\rho C_{0}^{2}}, k_{s}=\frac{K_{S}}{\rho C_{0}{ }^{2} B_{0}}, \\
& f_{i}=\frac{3 v}{B_{0} C_{0}} \cdots
\end{aligned}
$$
ただし， 


\section{3. 安 定 性 解 析}

$3 \cdot 1$ 定常解 定常状態で成り立つ関係式は, 支 配方程式と境界条件(2.1) (2.4)の時間微分項を除くこ とにより以下のように与えられる.

$$
\begin{aligned}
& r_{k}\left(b_{0}\right)-n_{0} \kappa_{0}=p_{0}-p_{e} \cdots \cdots \cdots \cdots \cdots \cdots \cdot(3.1) \\
& \left(b_{0} u_{0}\right)_{,_{x}}=0 \cdots \cdots \cdots \cdots \cdots \cdots \cdots \cdots \cdots \cdots \cdots \cdots(3.2 \mathrm{a}) \\
& \chi_{0} u_{0} u_{0}, x=-p_{0, x}-f_{i} g_{0} \frac{u_{0}}{b_{0}{ }^{2}} \cdots \cdots \cdots \cdots(3.2 \mathrm{~b}) \\
& b_{0}, x\left(x_{s 0}\right)=0 \cdots \cdots \cdots \cdots \cdots \cdots \cdots \cdots \cdots \cdots \cdots \cdots \cdots \cdots \cdots \cdots \cdots \cdots \cdots \cdots \\
& b_{0}(0)=b_{0}(l)=1 \cdots \cdots \cdots \cdots \cdots \cdots \cdots \cdots \cdot(3.4 \mathrm{a}) \\
& p_{0}(0)=p_{r}-\frac{1}{2}\left\{u_{0}(0)\right\}^{2}-l_{1} f_{i} u_{0}(0) \cdots \cdots(3.4 \mathrm{~b}) \\
& p_{0}(l)=l_{2} f_{i} u_{0}(l) \cdots \cdots \cdots \cdots \cdots \cdots \cdots \cdot(3.4 \mathrm{c})
\end{aligned}
$$

ただし， $\chi_{0}(x)=\chi\left(x, x_{s 0}\right), g_{0}(x)=g\left(x, x_{s 0}\right)$ であり, 添字 0 は定常状態での量を意味する.

$3 \cdot 2$ 摄乱方程式 各変数は定常解と之の周りの 微小な擾乱の和で表されると仮定する.

$$
\begin{aligned}
& b(x, t)=b_{0}(x)+b_{1}(x, t) \cdots \cdots \cdots \cdots \cdots \cdots \cdot(3.5 \mathrm{a}) \\
& p(x, t)=p_{0}(x)+p_{1}(x, t) \cdots \cdots \cdots \cdots \cdots \cdot(3.5 \mathrm{~b}) \\
& u(x, t)=u_{0}(x)+u_{1}(x, t) \cdots \cdots \cdots \cdots \cdots \cdot(3.5 \mathrm{c})
\end{aligned}
$$

添字 1 は微小な量を意味する.

さて, 系が定常状態から少しずれると, 剥離点の位 置 $x_{S}$ は剥離条件(2.3)を満たしながら移動する。この とき, $x_{s}(t)$ は，

$$
x_{s}(t)=x_{s 0}+x_{s l}(t)
$$

と表せる. そして，式(3.6)を式(2.3)の左辺に代入して $x=x_{s 0}$ の周りに Taylor 展開し， $x_{S 1}$ は微小であるから 2 次以上の項を無視し, さらに式(3.5a)を代入すると,

$$
\begin{aligned}
b,_{x}\left(x_{s}, t\right) & =b,_{x}\left(x_{s 0}+x_{s 1}, t\right) \\
& \cong b,_{x}\left(x_{s 0}, t\right)+b,_{x x}\left(x_{s 0}, t\right) \times x_{s 1}(t)+o\left(x_{s 1}{ }^{2}\right) \\
& =b_{0}, x_{x}\left(x_{s 0}\right)+b_{1}, x_{x}\left(x_{s 0}, t\right) \\
& +\left\{b_{0}, x_{x x}\left(x_{s 0}\right)+b_{1}, x x\right. \\
& \left.\left(x_{s 0}, t\right)\right\} \times x_{s 1}(t)
\end{aligned}
$$

となる. 三番目の式の右辺第 1 項は式(3.3)より 0, ま た右辺第 4 項は 2 次の微小量なので無視すると, 剥離 条件は最終的に,

$$
b_{1, x}\left(x_{s 0}, t\right)+b_{0}, x x\left(x_{s 0}\right) \times x_{s 1}(t)=0
$$

と表され，移項して以下の関係を得る.

$$
x_{s 1}(t)=-\frac{b_{1}, x_{x}\left(x_{s 0}, t\right)}{b_{0},_{x x}\left(x_{s 0}\right)}
$$

さらに，剥離点の移動に伴う擾乱を考慮した場合の $\chi$ と $f$ 分布関数は以下のようになる.

$$
\begin{aligned}
& \chi\left(x, x_{s}\right)=\chi_{0}(x)+\chi_{1}\left(x, x_{s}\right) \cdots \cdots \cdots \cdots \cdot(3.8 \mathrm{a}) \\
& f\left(x, x_{s}\right)=f_{0}(x)+f_{1}\left(x, x_{s}\right)
\end{aligned}
$$

$$
=f_{i} g_{0}(x)+f_{i} g_{1}\left(x, x_{s}\right) \cdots \cdots \cdots \cdot(3.8 \mathrm{~b})
$$

式(3.8a)の左辺の $x_{S}$ に式(3.6)を代入し， $x_{S 0}$ の周りに Taylor 展開し, 2 次以上の微小項を無視すると,

$$
\chi\left(x, x_{s 0}+x_{s 1}\right) \cong \chi_{0}(x)+\chi_{x_{s}}\left(x, x_{s 0}\right) \times x_{s 1}(t)
$$

となり，式(3.8a)の右辺と比較して，

$$
\chi_{1}\left(x, x_{s}\right)=\chi_{\hat{x}_{s}}\left(x, x_{s 0}\right) \times x_{s 1}(t)
$$

$g\left(x, x_{s}\right)$ についても同様にして,

$$
g_{1}\left(x, x_{s}\right)=g,_{x_{s}}\left(x, x_{s 0}\right) \times x_{s 1}(t)
$$

支配方程式(2.1)，(2.2)，境界条件(2.4)に式(3.5), (3.8)を代入し, $b_{1}, p_{1}, u_{1}, \chi_{1}, f_{1}$ に関して 2 次以上 の微小項を無視し, 定常状態で成り立つ関係式(3.1), (3.2)，(3.4)を用いて方程式を整理することにより，挸 乱方程式(3.10) と境界条件(3.11)が得られる.

$$
\begin{gathered}
m b_{1, t t}+c b_{1, t}+r_{k}, b\left(b_{0}\right) b_{1}-p_{1}-n_{0}\left\{1+\left(b_{0}, x\right)^{2}\right\}^{-1.5} b_{1}, x x \\
+3 n_{0} b_{0}, b_{x} b_{0}, x_{x}\left\{1+\left(b_{0},{ }_{x}\right)^{2}\right\}^{-2.5} b_{1}, x_{x}=0 \\
\cdots \cdots \cdots(3.10 \mathrm{a}) \\
b_{1, t}+b_{0} u_{1},{ }_{x}+b_{0},{ }_{x} u_{1}+u_{0} b_{1}, x_{x}+u_{0}, b_{1}=0 \cdots(3.10 \mathrm{~b}) \\
u_{1, t}+\chi_{0}\left(u_{0} u_{1},{ }_{x}+u_{0},{ }_{x} u_{1}\right)+\chi_{1} u_{0} u_{0}, p_{1}, x \\
+f_{i} g_{0}\left(\frac{u_{1}}{b_{0}{ }^{2}}-\frac{2 u_{0} b_{1}}{b_{0}{ }^{3}}\right)+f_{i} g_{1} \frac{u_{0}}{b_{0}{ }^{2}}=0 \cdots(3.10 \mathrm{c}) \\
b_{1}(0, t)=b_{1}(l, t)=0 \cdots \cdots(3.11 \mathrm{a}) \\
p_{1}(0, t)=-u_{0}(0) u_{1}(0, t)-l_{1} u_{1}, t(0, t)-l_{1} f_{i} u_{1}(0, t) \\
\cdots \cdots \cdots \cdots(3.11 \mathrm{~b}) \\
p_{1}(l, t)=l_{2} u_{1}, t(l, t)+l_{2} f_{i} u_{1}(l, t) \cdots \cdots \cdots(3.11 \mathrm{c})
\end{gathered}
$$

各挸乱の時間依存性を以下のように仮定する.

$$
\begin{aligned}
& b_{1}(x, t)=\operatorname{Re}(\widetilde{b}(x) \exp (s t)) \\
& u_{1}(x, t)=\operatorname{Re}(\tilde{u}(x) \exp (s t)) \\
& p_{1}(x, t)=\operatorname{Re}(\tilde{p}(x) \exp (s t))
\end{aligned}
$$

ただし， $s=\sigma+i \omega$ ( $i$ は虚数単位 $)$ であり, 実部 $\sigma$ は振 幅の増幅率, 虚部 $\omega$ は無次元化された角振動数を意味 する. 式(3.7)，(3.9)，(3.12)を擾乱方程式(3.10)に代 入し, 変数を列べクトルの形で整理すると, 最終的に 以下の線形常微分方程式が得られる.

$$
\begin{aligned}
& \mathbf{y}_{{ }_{x}}(x)=\mathbf{A}(x, s) \mathbf{y}(x)+\mathbf{B}(x) \mathbf{y}\left(x_{s 0}\right) \\
& \mathbf{y}(x)=\left[\begin{array}{llll}
\tilde{b} & \tilde{b},{ }_{x} & \tilde{p} & \tilde{u}
\end{array}\right]^{\mathrm{T}} \ldots \ldots \ldots
\end{aligned}
$$

ただし, 行列 $\mathbf{A}, \mathbf{B}$ の要素は, $a_{\mathrm{ij}}, b_{\mathrm{ij}}$ を行列 $\mathbf{A}, \mathbf{B}$ の $\mathrm{i}$ 行 $\mathrm{j}$ 列要素として，以下のように表される.

$$
a_{12}=1, \quad a_{21}=\frac{m s^{2}+c s+r_{k}, b}{n_{0}\left\{1+\left(b_{0}\right)\right.}
$$




$$
\begin{aligned}
& a_{22}=\frac{3 b_{0}, b_{0}, x_{x}}{1+\left(b_{0},{ }_{x}\right)^{2}}, a_{23}=-\frac{\left\{1+\left(b_{0}, x^{2}\right)^{2}\right\}^{1.5}}{n_{0}} \\
& a_{31}=\frac{s q \chi_{0}}{b_{0}{ }^{2}}-\frac{q^{2} \chi_{0} b_{0}, x}{b_{0}{ }^{4}}+\frac{2 q f_{i} g_{0}}{b_{0}{ }^{4}}, a_{32}=\frac{q^{2} \chi_{0}}{b_{0}{ }^{3}} \\
& a_{34}=-s+\frac{2 q \chi_{0} b_{0}, x}{b_{0}{ }^{2}}-\frac{f_{i} g_{0}}{b_{0}{ }^{2}}, a_{41}=-\frac{s}{b_{0}}+\frac{q b_{0}, x}{b_{0}{ }^{3}} \\
& a_{42}=-\frac{q}{b_{0}{ }^{2}}, \quad a_{44}=-\frac{b_{0}, x}{b_{0}} \\
& b_{32}=\frac{q f_{i} g,_{x_{s}}\left(x, x_{s 0}\right)-q^{2} b_{0,} \chi_{x} \chi_{x_{S}}\left(x, x_{s 0}\right)}{b_{0}{ }^{3} b_{0}, x_{x x}\left(x_{s 0}\right)}
\end{aligned}
$$

そのほかの要素は全て0である.また, 式(3.2a)より

$b_{0} u_{0}$ は $x$ に関して一定となるので $q \equiv b_{0} u_{0}$ とした

剥離点の移動に伴う擾乱は式(3.13a)の右辺第 2 項に

集約されており，この項を除くと Jensen の解析 ${ }^{(13)}$ と ほぼ等価な式が得られる。

境界条件についても同様にして，

$$
\mathbf{C}_{\mathbf{u}}(s) \mathbf{y}(0)=\mathbf{0}, \mathbf{C}_{\mathbf{d}}(s) \mathbf{y}(l)=\mathbf{0} \cdots \cdots \cdots(3.14)
$$
ただし，

$$
\begin{aligned}
& \mathbf{C}_{\mathbf{u}}=\left[\begin{array}{llll}
1 & 0 & 0 & 0 \\
0 & 0 & 1 & q+l_{1} f_{i}+s l_{1}
\end{array}\right], \\
& \mathbf{C}_{\mathbf{d}}=\left[\begin{array}{llll}
1 & 0 & 0 & 0 \\
0 & 0 & 1 & -l_{2} f_{i}-s l_{2}
\end{array}\right]
\end{aligned}
$$

$3 \cdot 3$ 固有值問題 線形常微分方程式(3.13)，境 界条件(3.14)からなる境界値問題を解くために, shooting 法を用いる.

計算手順として，まず，定常状態の支配方程式(3.1)， (3.2) 差分法により離散化し, 弾性膜の形状 $b_{0}(x)$ を 数値的に求める.これにより方程式(3.13)の行列 $\mathbf{A}$, B の各要素は末知数 $s$ ので表される. そして, $s$ の值 を変えながら，上流側の境界条件を満たすべクトル $\mathbf{y}(0)$ を用いて, 方程式(3.13)を下流へ向かって数值積 分し，下流側の境界条件を満たす $s$ を見つける.

得られた固有值 $s$ は擾乱の時間発展性を表し, $\sigma>0$ のとき定常解は不安定である.

\section{4. 結 果 と考 察}

数值解析において, Conrad ${ }^{(1)}$ と Ohba ら ${ }^{(5)}$ の実験を 参考にして，作動流体として $\rho=1000 \mathrm{~kg} / \mathrm{m}^{3}, v=1.0 \times 10^{-6}$ $\mathrm{m}^{2} / \mathrm{s}$ の水を考え, 弾性流路として, $E=1.6 \times 10^{5} \mathrm{~Pa}$, $H=0.001 \mathrm{~m}, v_{m}=0.5$ の二枚のゴム膜からなる， $L=0.2 \mathrm{~m}$, $B_{0}=0.01 \mathrm{~m}$ の流路を考える. また，特に断らない限り， 以下の無次元パラメーターの值を基隻値として用いる.

$$
\begin{aligned}
& m=c=0, h=0.1, k_{p}=0.047, k_{s}=56, a=10, \\
& f_{i}=0.00049, \varepsilon_{0}=0.2, p_{e}=0.5, l_{1}=l=l_{2}=20
\end{aligned}
$$

$a$ の値に関しては，大きく取ると計算上 $\chi, f$ の值が不 連続に変化してしまい, また, 小さすぎても現実的で はないので,ここでは任意に $a=10$ とした，また，弾 性膜の分割数 $\mathrm{N} を 200$, すなわち刻み幅 $\Delta x を 0.1$ とし, 式(3.13)で与えられる常微分方程式の数值解法として 二次精度の Runge-Kutta 法を用いる.

図 4 は, コラプシブルチューブの静特性を表す差压 $\Delta p\left(=p_{0}(0)-p_{0}(l)\right)$-流量 $q\left(=b_{0} u_{0}\right)$ 曲線上に, 定常状態 が不安定になる領域を振動モード別に表示している.

実線, 点線はそれぞれ安定, 不安定な領域を表し, 曲

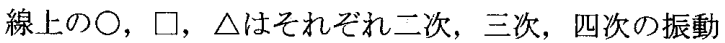
モードの不安定領域の限界を表す。この場合, 剥離点 の移動に伴う擾乱は考慮されていない，図中，系は二

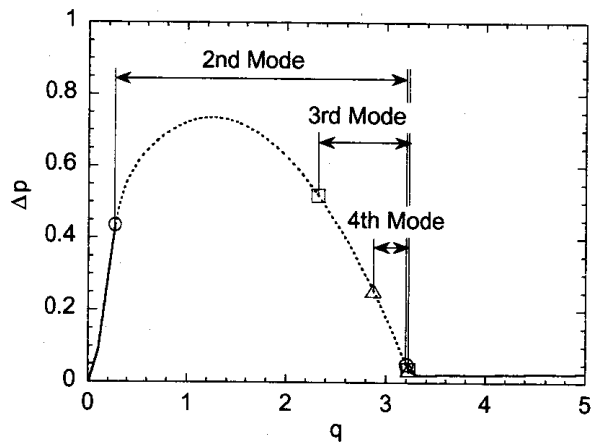

Fig.4 Stability of the steady states to each oscillatory mode, shown on the $\Delta p-q$ curve : the solid and dotted curves represent stable and unstable regions, respectively

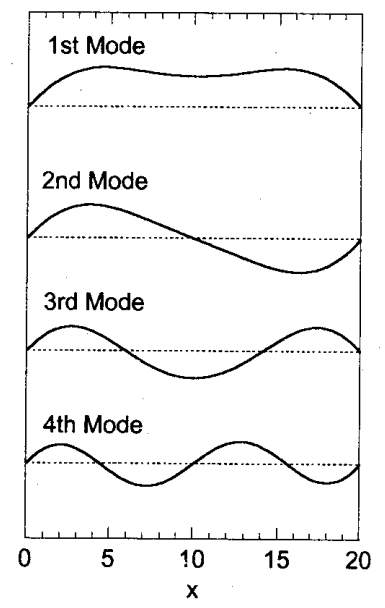

Fig.5 Shapes of the first to fourth oscillatory modes of the disturbance of a half-width of the channel, $b_{1}$, for $q=0$ 
次, 三次, 四次の振動モードに対して $0.27 \leq q \leq 3.20$, $2.32 \leq q \leq 3.22,2.87 \leq q \leq 3.22$ の範囲で不安定になってい る.二次の振動モ一ドに対する不安定領域が支配的で あり，高次の振動モードほど不安定領域は狭くなって いる.

図 5 に，q=0に対する, 流路半幅の擾乱 $b_{1}$ の一次か ら四次までの固有振動モードの形状を示す。ただし， 振動モードの次数は固有振動モードが 0 を横断する回 数の少ない順に決めた，また，次数が大きいほど対応 する固有角振動数の值も大きく，一次から四次の振動 モードの固有角振動数は順に $0.088,0.18,0.41,0.72$ である。理論的に無限個の振動モードが存在するが, 流れの支配方程式(1.2)を導出する際に長波長近似を用 いているため，高次の振動モードを考慮することは無 意味である. ゆえに, 解析では四次の振動モードまで を対象とする。

$4 \cdot 1$ 剥離点の移動に伴う擾乱の影響 表 1 は, 剥離点の移動に伴う擾乱の影響を調べた結果である. 剥離点の移動に伴う擾乱を考慮した場合, 二次の振動 モ一ドに対して小流量側の不安定限界は減少し，また， 四次の振動モードに対して大流量側の不安定限界は増 加するため, 全体の不安定領域は広がる. しかし，そ の影響は非常に小さい，この理由について考えてみる. 固有值問題の基礎方程式(3.13)において, 行列 $\mathbf{A}$ は一 つの定常解に対して不変であるので，行列 B のみが剥 離点の移動に伴う擾乱に関係する。しかし，行列 B 唯一の要素 $b_{32}$,

$$
\begin{aligned}
b_{32} & =\frac{q f, x_{s}\left(x, x_{s 0}\right)-q^{2} b_{0}, x}{b_{0}{ }^{3} b_{0},{ }_{x x}\left(x_{s 0}\right)}\left(x, x_{s 0}\right) \\
& =\frac{0.5 f_{i} a q-0.4 a q^{2} b_{0}, x_{x}}{b_{0}{ }^{3} b_{0}{ }_{x x}\left(x_{s 0}\right) \cosh ^{2}\left\{a\left(x-x_{s 0}\right)\right\}},
\end{aligned}
$$

は剥離点の近傍でのみ有限な值をとり，その範囲外の 大半の積分区間では 0 となる. 従って, 式(3.13)の解の 性質は主に剥離点の移動に伴う擾乱を含まない行列 $\mathbf{A}$ に左右され，行列 B は大勢に影響しないことが予想さ れる.このことは，式(4)のパラメーターの值に限らず， 他のパラメーターの值についても言えることであり， 一般的に剥㕍点の移動に伴う擾乱は小さいことが分か る.ゆえに, 以下の解析では剥離点の移動に伴う擾乱 は考慮しない。

Cancelli-Pedley は自励振動の主要な機構として剥離 点の移動が重要であると主張している(8). しかしなが ら, 本解析により, 自励振動が発生する段階, すなお ち定常流が不安定化する過程においては剥離点の移動
Table 1 Unstable regions for (A) the case where perturbations induced by the movement of separation point are taken into account and (B) the case where they are not taken into account

\begin{tabular}{|c||c|c|}
\hline & (A) & (B) \\
\hline \hline 1st Mode & Stable & Stable \\
\hline 2nd Mode & $0.26 \sim 3.20$ & $0.27 \sim 3.20$ \\
\hline 3rd Mode & $2.32 \sim 3.22$ & $2.32 \sim 3.22$ \\
\hline 4th Mode & $2.87 \sim 3.23$ & $2.87 \sim 3.22$ \\
\hline \hline Whole & $0.26 \sim 3.23$ & $0.27 \sim 3.22$ \\
\hline
\end{tabular}

はあくまでも二次的なものであり本質的でないことが 明らかになった。

また, Matsuzaki $ら^{(9)(10)}$ や Cancelli-Pedley ${ }^{(8)}$ が考慮 している剥離のヒステリシスも, 微小擾乱による剥離 点の移動量が少ないので, 剥離点の移動に伴う擾乱が 小さいことと同様に，定常流の安定性に関寸る限りほ とんど影響しないものと推察される.

$4 \cdot 2$ 下流流路長の影響 下流流路長による定常 状態の安定性への影響を整理したのが図 6 である．縦 軸に下流流路の長さ $l_{2}$, 横軸に流量 $q$ をとっている. また，零次から四次までの振動モードに対する不安定 領域の限界がそれぞれ $\nabla ， \diamond ， \bigcirc ， \square ， \triangle の$ 記号で示 され，各振動モードの不安定領域が(a)から(e)の図で表 示されている.ただし，ここでは一次の振動モードの うち固有角振動数が 0 になる場合を零次の振動モード と呼ぶことにする。また，各図において S，US はそれ ぞれ安定，不安定な領域を意味する。

$l_{2}$ が比較的小さい場合 $\left(l_{2}<100\right)$, 不安定領域において 二次の振動モードの範囲はほぼ全域を占め((c)), また, 三次，四次の振動モードになるにつれ不安定領域は狭 くなり，それらは大流量側の不安定限界付近に偏在し ている((d), (e)). 続いて $100<l_{2}<200$ で一次の振動モ一 ドに対する不安定領域が顕著になり((b))，同時に二次 の振動モードの不安定領域は中流量域から小流量, 大 流量側の各々の不安定限界に向かって狭くなる((c))). さらに $l_{2}$ を増加すると $\left(l_{2}>200\right)$, 中流量域において零 次の振動モードに対して系は不安定になり始め((a)), 徐々にその領域は拡大し支配的になる．この時点で三 次, 四次の振動モードの不安定領域は消失する((d), (e)で $l_{2}>300$ のとき).このように，定常解の安定性は 下流流路の長さと流量の組み合わせに強く依存し，下 流流路が長くなるに伴い全体の不安定領域の範囲は狭 まり，また，定常解が不安定となる振動モードのうち 支配的な振動モードは二次, 一次, 零次の順に変わる. 


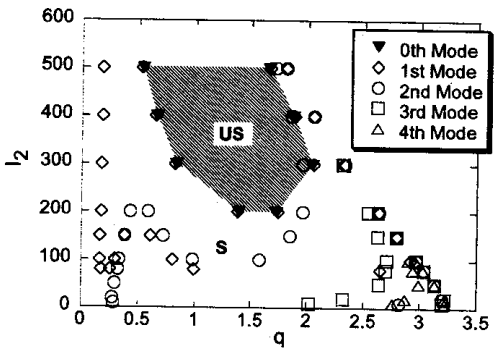

(a) Stability to the 0 th mode

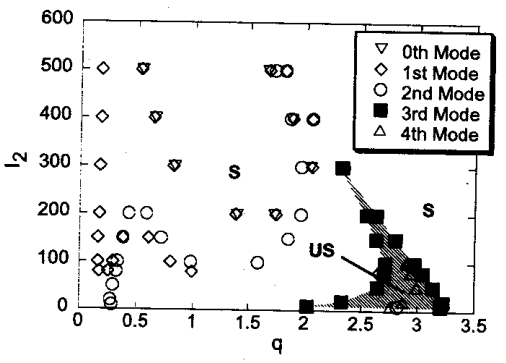

(d) Stability to the $3 \mathrm{rd}$ mode

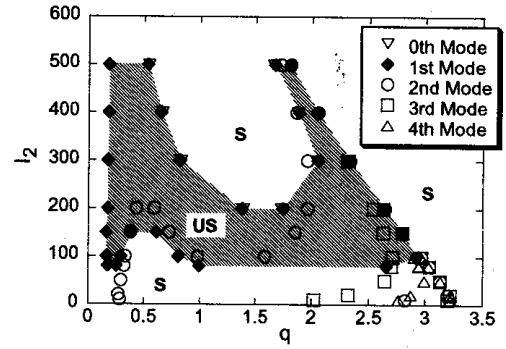

(b) Stability to the 1 st mode

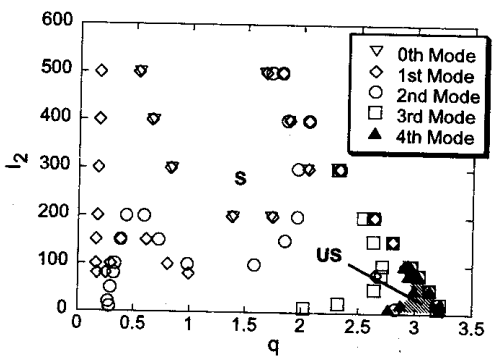

(e) Stability to the 4 th mode

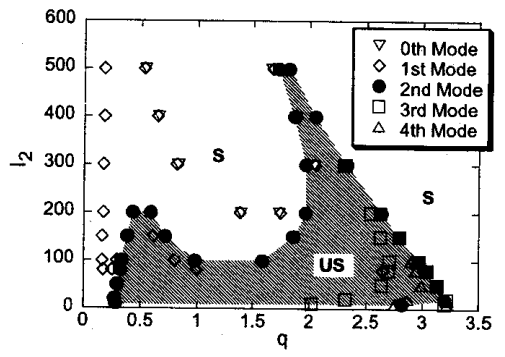

(c) Stability to the 2nd mode

Fig.6 Effect of the length of downstream rigid channel, $l_{2}$, on the stability of the steady solutions to each oscillatory mode

下流流路の長さと流量からなるパラメーター平面上 には, 単一の振動モードの不安定領域だけでなく, 複 数の振動モードの不安定領域が重なる部分もあり, そ れらの組み合わせも様々である，例えば， $\left(q, l_{2}\right)=(1.5$, $400)$ 付近では零次の振動モードのみ, $\left(q, l_{2}\right)=(2.0,100)$ 付近では一次, 二次の二つの振動モード, さらに， $(q$, $\left.l_{2}\right)=(3.0,20)$ 付近では二次, 三次, 四次の三つの振動玉一ドに対して定常解は不安定になる．コラプシブルチ ューブは下流流路抵抗の変化に対して様々な自励振動 のパターンを示すが(7)(9)，これは，自励振動が開始す るとき，すなわち，定常状態が不安定になるときの振 動モードの次数とそれらの組み合わせが少なからず反

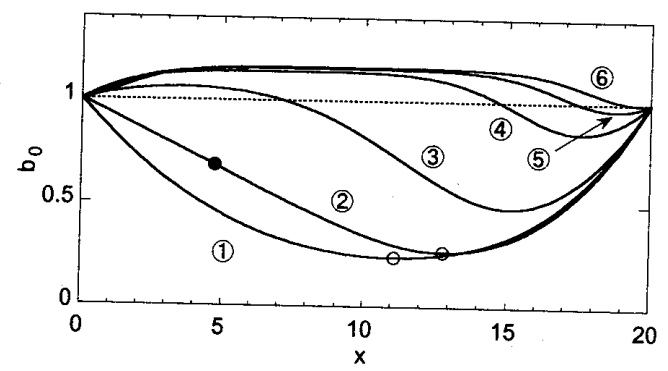

Fig.7 Representative channel shapes when the steady states are unstable to each oscillatory mode
映されているためと推測される.

不安定限界における定常状態の弾性膜の形状と振動 モードの関係について考察する. 図 7 に一次から四次 の振動モードに対して定常状態が不安定となる場合の 代表的な流路形状を示す．(1)〜(6)に対応するパラメ一 ターの值は，それぞれ $\left(q, l_{2}\right)=(0.17,300),(0.29,50)$, $(0.7,50),(2.02,10),(2.87,20)$ である.ただし，図にお いて $x$ 軸は弾性流路の中心軸に一致している.まず, 一次の振動モードに対する小流量側の不安定領域では, 弾性流路全体はつぶれ（1)，流路幅が最も狭いスロ

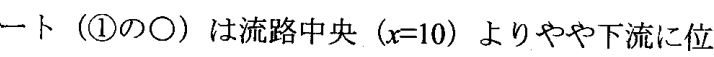
置している．二次の振動モードに対しては，小流量側 の不安定限界の極近傍では, 流路全体はつぶれている が (2)），一次の振動モ一ドの場合と比べてスロート

(2)の○) はさらに下流に位置し，スロートの上流に 変曲点（2)の○）が一つ存在する形状となる。また, 不安定領域ではスロートの上流側は上に凸の形状とな る（3）.さらに, 三次, 四次の振動モードに対して は, 小流量側の不安定領域では, 弾性流路の大半は膨 らみ（それぞれ(4)，(5)），下流端付近にそれぞれの振 動モードの形状の半波長に相当する長さ程度の狭窄部 が認められる.これらの弾性流路の形状はそれぞれの 振動モードが励起されやすいものとなっていると考え られる, 一方, 大流量側の不安定限界では, 前述の振 
動モード全てに共通して, 弾性流路はほぼ全域に渡り 膨らみ（6)）, 流路幅は下流端の近傍もしくは下流端 で極小となっている.

以上より, 不安定限界付近の定常状態においては, 弾性膜の形状と不安定となる振動モードの形状との間 に類似性が認められ, 弾性膜の形状が定常状態の安定 性に強く影響していることが分かる.

基準值である式(4)以外のパラメーターの値に対して． も, $q=0$ で流路全体がつぶれた状態から $q$ が増加し流 路全体が膨らむ状態に至るまでの間, 弾性流路の形状 は定性的に同じ過程を経て変化すると考えられる. 従 って, 前述したように不安定となる振動モードが弾性 流路の形状に強く依存することと合わせて考えると, 流量と下流流路長からなるパラメーター平面上におい て, 不安定となる振動モードの領域の傾向もまた式(4) 以外のパラメーターの值に対しても定性的には変わら ないと推測される.

\section{結言}

二次元弾性流路モデルに対して, 剥離点の移動に伴 う擾乱を考慮した損乱方程式を導出し, 剥離点の移動 に伴う挸乱と下流流路の長さが定常解の安定性に及ぼ す影響を調べた。その結果，以下のことが明らかにな った.

(1) 剥離点の移動に伴う, 剥離係数と粘性抵抗の分布 の変化は安定性にほとんど影響しない.

（2）定常解が不安定となる振動モードは下流流路の長 さと流量に強く依存し, 流路が長くなるに従って 支配的な振動モードは二次, 一次, 零次の順に変 わる.
(3) 不安定限界付近の定常状態における弾性膜の形状 と不安定となる振動モードの形状との間に類似性 が認められ, 弾性膜の形状が定常状態の安定性に 強く影響していることが分かった。

\section{文献}

(1) Kamm, R. D. and Pedley, T. J., Trans. ASME, J. Biomech. Eng., 111(1989), 177-179.

（2）池田 - 松崎, 機論, 60-572, B(1994), 1226-1233.

(3) 辻・ほか 8 名, 人工臟器, 7(1978), 435-438.

(4) Conrad, W. A., IEEE Bio-Med. Eng., BME-16(1969), 284-295.

(5) Ohba, K, ほか 3 名, Technol. Rep. Kansai Univ., 25(1984), 1-13.

(6) Matsuzaki, Y., ほか 3 名, Trans. ASME, J. Biomech. Eng., 120(1998), 594-601.

(7) Bertram, C. D., ほか 2 名, J. Fluids Struct., 4(1990), 125-153.

(8) Cancelli, C. and Pedley, T. J., J. Fluid Mech., 157(1985), 375-404.

(9) Matsuzaki, Y. and Matsumoto, T., Trans. ASME, J. Biomech. Eng., 111(1989), 180-184.

(10) Matsuzaki, Y., ほか 3 名, Trans. ASME, J. Biomech. Eng., 116(1994), 469-476.

(11) Ikeda, T. and Matsuzaki, Y., Trans. ASME, J. Biomech. Eng., 121(1999), 153-159.

(12) Jensen, O. E. and Pedley, T. J., J. Fluid Mech., 206(1989), 339-374.

(13) Jensen, O. E., J. Fluid Mech., 220(1990), 623-659.

（14）例えば, Kececioglu, I,,ほか 3 名, J. Fluid Mech, 109(1981), 367-389.

（15） Elad, D., ほか 2 名, Trans. ASME, J. Biomech. Eng., 109(1987), 1-9. 